\title{
MOVING FROM PRODUCTION TO SERVICES: A BUILT ENVIRONMENT CLUSTER FRAMEWORK
}

\section{Jean CARASSUS ${ }^{1}$, Niclas ANDERSSON ${ }^{2}$, Artūras KAKLAUSKAS ${ }^{3}$, Jorge LOPES ${ }^{4}$, André MANSEAU ${ }^{5}$, Les RUDDOCK ${ }^{6}$ and Gerard de VALENCE ${ }^{7}$}

1 Economics and Human Sciences Department, Centre Scientifique et Technique du Bâtiment, 4 Avenue du Recteur Poincaré, 75782 Paris Cedex 16, France. E-mail: carassus@cstb.fr

2 Department of Civil Engineering, Technical University of Denmark, Building 115, DK-2800, Kgs. Lyngby, Denmark. E-mail: na@byg.dtu.dk

3 Department of Construction Economics and Property Management, Vilnius Gediminas Technical University, Sauletekio al. 11, 10223 Vilnius, Lithuania

E-mail: Arturas.Kaklauskas@st.vtu.lt

4 Department of Construction and Planning, Polytechnic Institute of Bragança, Apartado 134, 5301-857 Braganca, Portugal. E-mail: Lopes@ipb.pt

5 Université du Québec en Outaouais, Canada

E-mail: andre.manseau@uqo.ca

6 Research Institute for the Built and Human Environment, University of Salford, Salford M5 4WT, United Kingdom

E-mail: L.Ruddock@salford.ac.uk

7 Department of Project Management, University of Technology Sydney, Broadway NSW 2007, Australia. E-mail: g.devalence@uts.edu.au

Received 24 January 2006; accepted 10 April 2006

\begin{abstract}
The construction industry is no longer focused on providing a single product - i.e. a building or a physical infrastructure, but a variety of services and improvement to the human environment. Major trends such as Performance-based Building as well as Sustainable Built Environment are calling for major changes. These changes mean additional roles for the industry as well as the need for new indicators to measure its performance and its economic impact. This paper proposes a new approach based on the development of a framework for the analysis of the entire construction and property sector - the "built environment cluster". It extends the analysis of an international study based on nine countries Australia, Canada, Denmark, France, Germany, Lithuania, Portugal, Sweden, and the United Kingdom. The need for improving statistical data is stressed particularly in the context of enlarging the scope of the industry. This new approach provides an excellent starting point for developing new performance indicators that will take into account the changing nature of the industry, for an integrative perspective providing a basis for strategic management, for studying sustainable development in construction and for understanding innovation processes and changes. A comprehensive perspective of the industry performance is crucial for policy initiatives as well as for strategic analysis of firms.
\end{abstract}

KEYWORDS: Built environment cluster; Construction and property sector; Developed countries; International comparison; Mesoeconomics

International Journal of Strategic Property Management

ISSN 1648-715X print / ISSN 1648-9179 online @ 2006 Vilnius Gediminas Technical University

http://www.ijspm.vgtu.lt 


\section{INTRODUCTION}

The built environment cluster analysis provides an innovative and exciting approach to analyse operations and functions of the construction sector within a country's overall economy.

Carassus (1998, 2000) put forward initial ideas for developing a framework for the analysis of the entire construction and property sector of the economy. A Project Group was later set up by Working Commissions W55 (Building Economics) and W65 (Organisation and Management of Construction) of the CIB (International Council for Research and Innovation in Building and Construction) to consider the framework in the context of a set of case study applications. The membership of the Group was also drawn from a team working in a CIB Task Group (TG31 Macroeconomic Data for the Construction Industry), as it was recognised that the proposed mesoeconomic approach supplemented existing methods of viewing the industry in order to cover the entire construction and property sector.

The work of the Project Group resulted in the mesoeconomic approach being tested in nine diverse countries. (The final report is available at www.cibworld.nl/pages/-begin/ Pub293.pdf). Each country's specific situation and characteristics are considered in the analysis and the notion of the built environment cluster presents a unifying approach.

This paper summarises the key findings from the CIB Report and extends its analysis providing a more comprehensive perspective and additional implications for strategic management, innovation processes and policy development. The CIB report and Carassus work put forward the "construction sector system" notion. This notion can be interpreted as focusing the analysis on production and on construction firms. This paper extends the approach to the "built environment cluster" notion, which underlines both the importance of the stock (built structures) and services activi- ties (cluster of firms and organizations involved in developing and maintaining the built environment).

\section{FROM THE CONSTRUCTION INDUSTRY TO THE BUILT ENVIRONMENT CLUSTER}

The rationale for the new approach is based on the fact that the construction and property sector is now playing a new role within the economy of developed countries. It is no longer focused on large-scale production but on the services provided by the built environment. The economic growth experienced by most developed countries between the late 1940s and the beginning of the 1970s was succeeded by a recession lasting until the beginning of the 1990s in the United States and until the end of the last decade in Europe. This period of recession was a time of transformation.

In the general evolution of the economy, what kind of transformation did the construction industry in developed countries face during those changing times? Between the late 1940 s and the beginning of the 1970s, the role of the construction industry was to complement the significant and relatively regular economic growth through the development of large-scale housing projects, non-residential buildings and civil engineering infrastructures.

The dimension of the construction stock developed within the growth phase has become highly significant in several developed countries. Recently, the refurbishment and maintenance works of such stock in France, the United Kingdom, Italy and the Scandinavian countries, amounts to approximately half of construction organisations' business, including civil engineering projects. Furthermore, both firms and public authorities have turned the upgrading and management of their stock into an area of increasing concern. The quality and the reasonable cost of the service rendered by their buildings and civil engineering infrastructures have become of the essence. The stock is becoming a research object (Kohler and 
Hassler, 2002). The popularity gained by the 'Facilities Management' trend translates this concern, while the professionalisation of inhouse building management or the outsourcing of this management are being fostered. Flexibility of use and maintenance cost are becoming two criteria for managing large facilities.

The expansion of processes not only in charge of production but also built environment management, over long periods of time, reflects the same evolution. In fact, several mechanisms such as the Private Finance Initiative (PFI) and Private and Public Partnership (PPP) have been created to foster such a trend. Such evolution is all the more marked as the profitability of service activities related to maintenance and management is higher and less cyclic than construction site activities.

It is apparent, therefore, that the change faced by the construction industry in the 1990s changed its role within the economy. Whilst, until the 1970s, the goal of construction was to massively build all the works necessary to meet the needs of the economy, since the nineties, the emphasis has been placed on the management of the service rendered by such works all along their life cycle.

Performance-based buildings approach highlights the service to be provided (Hammond et al, 2005; Sexton and Barrett, 2005).

The requirements of sustainable development, which focus on the need to increasingly master medium and long-term consequences, not only regarding production, but also management of the works during their whole life cycle have strengthened this change of role within the economy (Curwell and Cooper, 1998; Bourdeau, 1999; Brandon, 1999). This focus on the service rendered by the works calls for a new approach for the analysis of the construction and property sector.

Economic analysis has to take into account such recent evolution and all the participants involved in the life cycle of building structures (not only procurement, design and production but also operation, maintenance, refurbishment and demolition). Traditional construction industry analyses deal with construction firms principally. Some research analyses have included the industry professions and the materials industry, but not the service aspects and the stock management firms. The aim of this work is: To present the built environment cluster framework, which includes the production, service, management and stock aspects of construction and test this framework in nine developed countries.

\section{AN OVERVIEW OF PREVIOUS STUDIES}

The study of the construction industry and its role in the national economy has been extensively researched. At the macro level, existing assumptions persist that structural changes will emerge in the construction industry of a particular country as the national economy develops over time. Turin (1973), in his analysis of the role of the construction sector in economic development presented a development pattern of the construction industry based on stages in an economy's development. The main aspects of the development pattern were that, in the early stages of development, the share of construction in national output first grows at an increasing rate and then at a decreasing rate compared with the level of national income. This ' $\mathrm{S}$ ' shape pattern contrasts with Bon's (1992) inverse ' $U$ ' shape pattern in which the share of construction in national output increases in the early stages of development but ultimately will decrease in absolute and relative terms in more advanced industrial countries. Another important aspect of the development pattern derived from the latter work is that, whilst the share allotted to improvement and maintenance in total construction increases, the proportion for new construction decreases in the latest stages of development. Ruddock (1999), using more recent data collected from a large sample of countries representing all stages of economic development corroborated this proposition.

The role of the construction industry in the 
national economy has also been explored by several writers through the use of input-output tools. Because of its double accounting framework, input -output tables are well suited to the analysis of the interdependence between the construction industry and other industries forming the national economy. Some of these works (Bon, 1991; Bon and Pietroforte, 1993; Pietroforte and Gregory, 2002, amongst others) have focused on the change in sectoral shares, and also on the study of the direct and indirect resource utilisation by the construction sector, both at country level and in comparative historical analysis across advanced industrial countries.

Differing views on the role of the construction industry in the national economy have been put forward. De Long and Summers (1991), using data drawn from more than 60 countries of all continents, and for the period 1960-1985, found no significant association between construction investment and economic growth. Lopes (1998), in his study of the construction sector of developing countries in Africa, posited that the growth in the construction sector should follow that of the general economy. These somewhat contrasting views on the role the construction sector plays in the national economy are perhaps associated with the issues derived from data definitions and measurement problems pertaining to the construction industry, both at country and international levels. The development of a singleagency responsibility for data collection and the setting up of regional construction databases are pertinent in this context (Ruddock, 2000).

At the sectoral level, writers often analyse the way the construction firm operates within the sector's particular environment (Hillebrandt, 1985; Briscoe, 1988; Manser, 1994). Experts' reports are centred on the relationship between the construction firm and its client and the designer (Latham, 1994; CIB, 1997; Egan, 1998). The approach in terms of a supply chain integrates materials manufacturers (London and Russell, 1999). Studies dealing with the construction industry (Finkel,
1997), occasionally include the industry's professions (Ball, 1988). Overall or cluster approaches are rarer (Atkins, 1993; AEGIS, 1999; Ive and Gruneberg, 2000a and 2000b). Studies in the French language deal with the construction industry taking into account in particular the problem of land (Ascher and Lacoste, 1972; Lipietz, 1974), on-site work processes (Campinos-Dubernet, 1984, 1996; du Tertre, 1989, 1991) and demand (Berthier, 1992). Some studies, using the notion of the production chain, have stressed the technical dimension (Chemillier, 1977), the development aspect (Vincent, 1986) or are based on an overall approach (Boublil, 1980; Carassus, 1987).

The cluster approach has also been useful in studying innovation processes in construction (Bernstein, 1996; Manseau, 1998; Slaughter, 2000).

\section{MESOECONOMICS: AN UNUSUAL APPROACH}

Mesoeconomics is the intermediate level (in Greek, meso means "median") between the microeconomic one and the macroeconomic one (Holland, 1987). Microeconomics deals with individuals and firms being profitable in a market of scarcity. Further, it explains how actions of all buyers and sellers determine prices and how prices influence the decisions and actions of individual buyers and sellers (Perloff, 2001).

The mesoeconomic approach proposed implies a system analysis of the construction and property sector i.e. the built environment cluster, which is constituted by economic and participant institutions that are to solve a production issue concerning socially necessary goods or services. The built environment cluster analysis is based on the notions of aim of the construction activity, shaping characteristics, groups of activities, profit formation, fragmentation, operational configurations of players and institutional regulations (Carassus, 1998, 1999). Table 1 summarises the main differences between the usual construction indus- 
try analysis and the built environment cluster approach.

\section{METHODOLOGY}

The built environment cluster is made up of interacting components that perform economic activities during the lifetime of a structure under the external influence of the environment of the system. The design of the built environment cluster rests on the assumption that the general framework has the same structure and contents for more than one construction and property system (Andersson, 2003). This implies that the main economic activities of manufacture, production and as- set management as well as the life cycle and the phases of the construction process are the same for construction sectors in different countries. The principle follows the line of thought that every building or construction goes through the same process of activities. On the other hand, the components of the built environment cluster, i.e. the actors who carry out the economic activities, may differ from one country to another.

The economic activities are described along the vertical axis in the framework, dividing it into three sections: construction life cycle, built environment cluster, institutional environment.

The various actors constitute the components of the framework according to the con-

Table 1. Main differences between construction industry analysis and the built environment cluster approach

\begin{tabular}{|c|c|c|}
\hline & $\begin{array}{l}\text { Construction industry } \\
\text { analysis }\end{array}$ & Built environment cluster approach \\
\hline The industry aim & $\begin{array}{l}\text { To build buildings and } \\
\text { infrastructures }\end{array}$ & $\begin{array}{l}\text { To produce and to manage the services provided by the structures } \\
\text { throughout their life-cycle }\end{array}$ \\
\hline $\begin{array}{l}\text { Role of the existing } \\
\text { stock }\end{array}$ & Not taken into account & $\begin{array}{l}\text { Very important role of the existing stock: } \\
\text { - Weight of the stock } \\
\text { - Large part of the repair \& maintenance works } \\
\text { - Important role of stock management }\end{array}$ \\
\hline Shaping characteristics & $\begin{array}{l}\text { Prototype } \\
\text { Site }\end{array}$ & $\begin{array}{l}\text { Diversity and heterogeneity of orders } \\
\text { Immobile products (prototype, site) }\end{array}$ \\
\hline Activities & Construction firms & $\begin{array}{l}\text { Stock management firms } \\
\text { Project/site (clients, engineering, construction) firms } \\
\text { Industry (materials, machinery) and distributors }\end{array}$ \\
\hline Profit formation & Depending on cycles & $\begin{array}{l}\text { Stock management: recurrent, non cyclical, high } \\
\text { Project/site: cyclical, low } \\
\text { Industry: depends on the industry, linked to the cycle }\end{array}$ \\
\hline Fragmentation & $\begin{array}{l}\text { Weight of SMEs and self - } \\
\text { employed }\end{array}$ & $\begin{array}{l}\text { Differentiated fragmentation depending on: } \\
\text { - Fragmentation of the order } \\
\text { - Degree of technical complexity } \\
\text { - Capital intensity }\end{array}$ \\
\hline Processes & Especially new construction & $\begin{array}{l}\text { Three kinds of construction business systems: } \\
\text { - Production } \\
\text { - Production \& management } \\
\text { - Management }\end{array}$ \\
\hline $\begin{array}{l}\text { Institutional } \\
\text { regulations }\end{array}$ & Often taken into account & $\begin{array}{l}\text { Structures regulations (building permits, construction codes, product } \\
\text { and service certification) } \\
\text { Firms regulations (firms standards, labour management, prices) } \\
\text { Environment of the firms' regulations (procurement methods, funding, } \\
\text { tax, R\&D support, education and training). }\end{array}$ \\
\hline
\end{tabular}


struction activities they perform, and the phases of the life cycle they support. The cluster is presented as a matrix crossing three types of firms (services firms, on site production firms, manufacturing firms) and three types of economic activities (firstly asset, property, facilities and transaction management, secondly project management and on site production, thirdly manufacturing and distribution). Services firms are present in the three types of activities, on site production firms mainly in one type, manufacturing in one type (see Figure 1).

The matrix highlights the difference between the construction sector approach limited to the construction firms and the built environment cluster including the manufacturing firms and all the services firms.

Figure 2 describes the main functions and regulations of a built environment cluster. Asset, property, facilities and transaction management is undertaken by services firms involved in ownership, operation, maintenance, purchase, sales activities. Project management and on site production are provided by services firms dealing with briefing, design, technical studies, co-ordination, control and by construction firms involved in new construction, major repairs, refurbishment and demolition works. Manufacturing and distribution are made by materials, components, equipment, and machinery manufacturers and by services firms for distribution.

As the cluster is described as an open system, the external environment (i.e. the surrounding market and regulations) influences it. Mesoeconomics specifically takes into consideration influence of the institutional environment to the industry cluster. Different institutional actors, including the international institutions down to trade unions and tenants' associations, represent the institutional environment (see Table 2).

Due to the fact, in particular, that structures are large and static on site for many years, with all the implications for users and neighbourhood (quality of life and the environment, safety, high cost of defaults) the cluster is mediated by a large number of institutional regulations. These regulations may concern the structures (building permits, construction codes, product and service certification), the firms (firms' standards, labour management, prices), the environment of the firms (procurement methods, funding, tax, R\&D support, education and training). They are defined and

\begin{tabular}{|c|c|c|c|c|}
\hline & \multicolumn{4}{|c|}{ Construction life cycle } \\
\hline \multirow{5}{*}{ 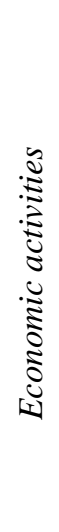 } & \multicolumn{4}{|c|}{ Built environment cluster } \\
\hline & & Services firms & $\begin{array}{l}\text { On site } \\
\text { production } \\
\text { firms }\end{array}$ & $\begin{array}{l}\text { Manufacturing } \\
\text { firms }\end{array}$ \\
\hline & $\begin{array}{l}\text { Asset, property, } \\
\text { facilities, transaction } \\
\text { management }\end{array}$ & X & & \\
\hline & $\begin{array}{l}\text { Project management } \\
\text { and on site } \\
\text { production }\end{array}$ & X & X & \\
\hline & $\begin{array}{l}\text { Manufacturing and } \\
\text { distribution }\end{array}$ & X & & X \\
\hline & \multicolumn{4}{|c|}{ Institutional environment } \\
\hline
\end{tabular}

Figure 1. Outline of the built environment cluster 


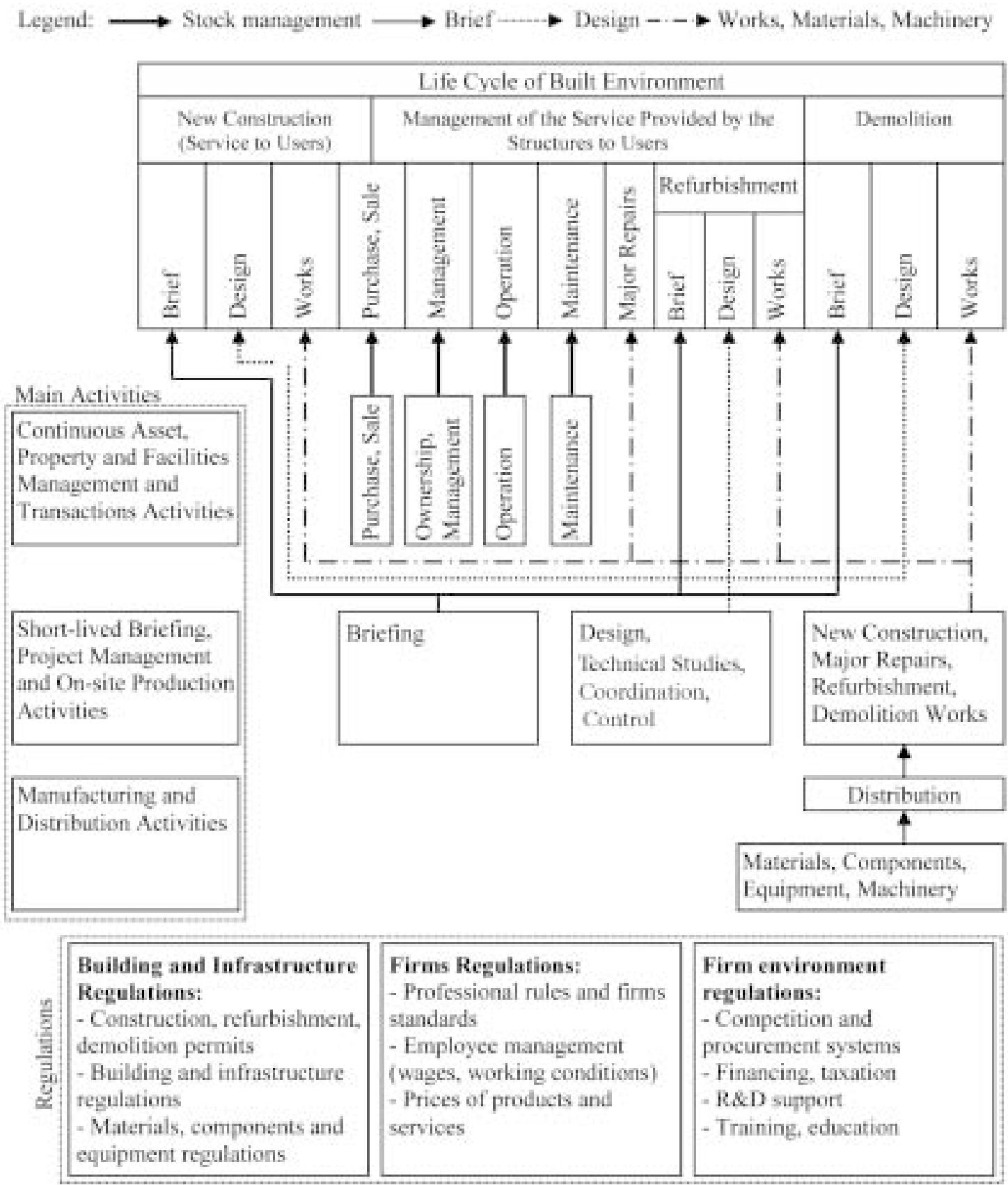

Figure 2. Built environment cluster: the main functions and regulations 
Table 2. Institutional participants and main types of regulations (schematic matrix)

\begin{tabular}{|c|c|c|c|c|c|c|c|c|c|}
\hline & \multicolumn{3}{|c|}{ Building and Materials } & \multicolumn{3}{|l|}{ Firms } & \multicolumn{3}{|c|}{ Environment of the Firms } \\
\hline Regulations & 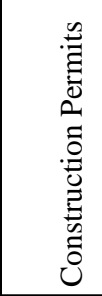 & 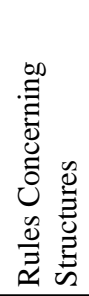 & 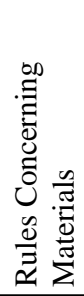 & 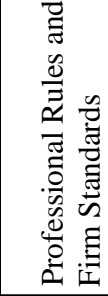 & 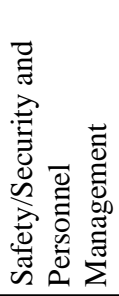 & 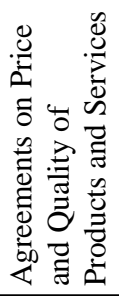 & 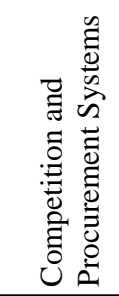 & 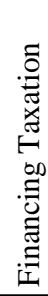 & 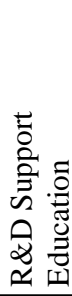 \\
\hline $\begin{array}{l}\text { International } \\
\text { institutions }\end{array}$ & & & & & & & & & \\
\hline Government & & & & & & & & & \\
\hline $\begin{array}{l}\text { Regional and local } \\
\text { authorities }\end{array}$ & & & & & & & & & \\
\hline $\begin{array}{l}\text { Client, industrial, } \\
\text { professional } \\
\text { organisations }\end{array}$ & & & & & & & & & \\
\hline Trade unions & & & & & & & & & \\
\hline Users associations & & & & & & & & & \\
\hline
\end{tabular}

applied by a complex system of public institutions (international, national, regional, and local) and private institutions (industrial, unions, and consumer organisations).

Table 2 sums up, in a schematic matrix, the main types of regulations and institutions concerned in the built environment cluster approach.

\section{KEY FINDINGS OF THE CASE-STUDY BUILT ENVIRONMENT CLUSTERS}

The test of the built environment cluster analysis shows that the approach is applicable for the analysis of the construction sectors in the nine studied countries. Furthermore, the common cluster framework provides a basis for international comparisons.

The case study of the nine countries highlights differences related to institutional contexts, clients' orders and actors. But it emphasizes significant similarities about the growth of services, the relative decline of the construction industry, the importance of the built environment cluster, the significance of the stock and of its maintenance and the coexistence of big companies with a very fragmented system.

\section{Institutional contexts are different}

Among the nine countries, the institutional contexts are different. Using Boyer (1996) typology, implemented by Winch (2000a) for the analysis of construction business systems in Europe, four main institutional contexts can be differentiated.

The characteristic of the anglo-saxon context is the reliance upon liberal market values, the relatively low state regulation, the reliance on the stock market for industrial finance and the relatively low levels of worker protection. This characterises the context of the built environment clusters in the UK, Canada and Australia, even if differences are significant between the three countries.

The social-democrat context is characterised by the reliance on tripartite agreements (stateemployers-unions), the reliance on strong unions and the high levels of worker protection. This is the institutional context of the Danish and Swedish built environment clusters.

The German context can be termed corporatist with negotiated coordination between the social partners, greater willingness to intervene in the market to protect social values, 
greater reliance on banks for industrial finance and relatively high levels of worker protection.

The French and Portuguese institutional contexts are public, because the state has a vital role in coordinating and financing the economy. The protection of worker conditions is relatively strong.

Finally, a transitional institutional context can be added, where an economy is in transition from a planned economy to a market economy. Public firms are massively privatised and a new public regulation has to be set up. Lithuania is in that situation.

In spite of strong differences among the five institutional contexts, the significance of the government regulation in the construction sector system is a common characteristic among the nine countries.

Concerning international regulation, there is considerable distinction between European Union countries and the others. Among the anglo-saxon group, this explains the differences between the UK on the one hand, and Canada and Australia on the other. The role of the European Union in regulating the built environment cluster is increasing. This role is especially high in materials regulation, competition and procurement systems, safety and environmental issues, financing and $R \& D$.

Among the anglo-saxon group, in spite of the market-oriented context, the role of government regulations is very significant in construction.

Among the social-democrat group, the role of regional and local authorities' regulation in Denmark and in Sweden principally concerns the urban planning process, building permissions etc. The role of central government has historically been strong in both Denmark and Sweden, e.g. through rules and regulations, subsidies and supporting measures. However, both countries deregulated the construction sector in the 1990s.

In Germany, the role of central and regional government in industrial and professional organisations regulation is great. In the French and Portuguese public context, central government and industrial organisations are strong, but the role of the unions and user associations is weak. In the Lithuanian transitional context, a new role of central government and industrial organisations has to be specified. The role played by unions and user associations' is very weak.

\section{Clients and orders are varied}

The part played by civil engineering is very strong in Canada and in Lithuania for different reasons. The high level of new engineering works in Canada can be explained by the industrial and economic structure of the country. An important share of industrial activities is based on exploiting natural resources, such as gas and oil, mining and forestry activities, as well as on transforming these raw material into added-value products, such as pulp and paper, primary metal and alloys, and chemical industries. Canada is also a large country, which still has a rather low density of population in comparison with many other countries. New roads, bridges and various municipal and communication infrastructures are still expanding in the country. In Lithuania the civil engineering sector is strong, but the housing sector is presently very weak (see Table 3 ).

Table 3. Residential, non-residential, civil engineering shares of total construction output

\begin{tabular}{llllllllll}
\hline$\%$ & $\begin{array}{l}\text { Australia } \\
(2003)\end{array}$ & $\begin{array}{l}\text { Canada } \\
(2004)\end{array}$ & $\begin{array}{l}\text { Denmark } \\
(2004)\end{array}$ & $\begin{array}{l}\text { France } \\
(2003)\end{array}$ & $\begin{array}{l}\text { Germany } \\
(1999)\end{array}$ & $\begin{array}{l}\text { Lithuania } \\
(2003)\end{array}$ & $\begin{array}{l}\text { Portugal } \\
(2002)\end{array}$ & $\begin{array}{l}\text { Sweden } \\
(2002)\end{array}$ & $\begin{array}{l}\text { UK } \\
(2003)\end{array}$ \\
\hline Residential & 44 & 36 & 54 & 43 & 57 & 10 & 52 & 33 & 39 \\
$\begin{array}{l}\text { Non } \\
\text { residential }\end{array}$ & 21 & 18 & 29 & 34 & 27 & 51 & 21 & 37 & \\
$\begin{array}{l}\text { Civil } \\
\text { engineering }\end{array}$ & 35 & 45 & 17 & 23 & 16 & 39 & 27 & 30 & 61 \\
\hline
\end{tabular}


The civil engineering sector is quite strong in Australia, which has common characteristics with Canada. Among the building works in Europe, the share of residential works is currently high in Germany, Denmark and Portugal (see Table 3).

The repartition of construction works is changing in each country. It depends on the evolution of the demand of the different clients. Currently, the share of government (central and especially local government) varies from 15 to $28 \%$, if the specific case of Lithuania is excluded. The share of household demand is particularly weak in Sweden (see Table 4).

The functions of the cluster are the same, but the actors are different

The functions of the cluster are the same in the nine countries, but the actors implementing those functions may be different. For instance, general contracting has been the dominant business system in UK since the beginning of the $19^{\text {th }}$ century (Winch, 2000b), while separated trades are common in continental Europe. Additional to dealing with the general contractor, the anglo-saxon client is advised by quantity surveyors. Apart from Australia, this profession does not exist in the other countries in the study.

Controllers are often public, but are private in France. French "Bureaux de contrôle" have no equivalent in other countries. In France, land developers are different from buildings developers. Such distinction does not exist in the UK. Cooperatives for building and managing built facilities are strong in Denmark, Germany and Sweden. They are weak or absent in the other countries.

Even when an actor has the same name in the different countries, his/her role may be different. The role of the architect is stronger in the UK, Germany and Denmark than in France or Sweden. In Canada, the role of architects and design engineers has been increasingly important. In addition to design and the increasing popularity of design and build contracts, they are usually responsible for quality control throughout the entire building process.

The construction business systems may be very different. "Perhaps the most radical innovation in the UK construction industry for 200 years is the introduction of concession contracting" (Winch, 2000b, p. 153), whereas concession contracting has been implemented in France since the $16^{\text {th }}$ century.

The importance of the construction industry is declining. The built environment cluster is twice as large

The share of construction value-added in GDP is declining in all the countries, except Portugal and Lithuania. Bon (1997) and Ruddock (1999) noticed the link between the level of economic development and construction industry weight. Most of the time, the construction industry's share is declining in very developed countries and is increasing in other countries. The Portuguese and Lithuanian construction levels are lower than in the other countries.

The general trend is simultaneous with the rise of the tertiary sector. In several countries (France, Germany, UK), manufacturing industry also represents a declining share of the GDP.

Within this common trend, conjuncture may be different from one country to another, depending on the construction business cycle. In 1997-1999, construction value-added increased

Table 4. Total construction output according to demand

\begin{tabular}{lllllll}
\hline$\%$ & $\begin{array}{l}\text { Australia } \\
(2003)\end{array}$ & $\begin{array}{l}\text { France } \\
(2003)\end{array}$ & $\begin{array}{l}\text { Germany } \\
(2000)\end{array}$ & $\begin{array}{l}\text { Lithuania } \\
(2003)\end{array}$ & $\begin{array}{l}\text { Sweden } \\
(1999)\end{array}$ \\
\hline Households & 31 & $35^{*}$ & 25 & 59 & 14 & 24 \\
Firms & 54 & 39 & 47 & 41 & 61 & $2503)$ \\
Government & 15 & 26 & 28 & 41 & 27 \\
\hline
\end{tabular}

* households and real estate developers 
in Australia, but shrunk in Canada, Sweden and Denmark. Even between two neighbouring countries, construction cycles can be very different. In 2000-2003, the cycle was upward in France, but declining in Germany (see Figure 3 ).

At the beginning of the $21^{\text {st }}$ century, the construction industry share of GDP is around 4 to $6 \%$ in the more developed countries in the study. The built environment cluster is about twice as big as the narrowly-defined construction industry. In Canada, for instance, construction firms value-added was $5.4 \%$ of GDP in 1999. Building products, construction equipment, design, technical services, built facilities operation and maintenance count for about $6 \%$.

The construction share of national employment has increased in Portugal till 2000, but not, until recently, in Lithuania. A construction boom began in 2002 and has continued underpinned by favourable financial conditions. In the most developed countries, the share of construction employment is steady (see Figure 4).

In the more developed countries of the study, construction industry employment represents around $6 \%$ of total employment (a little more in Australia). The built environment cluster employment is more than twice as big. In the Canadian construction industry, the workforce in 2000 was 900000 . Design and engineering employed 180000 , building products and equipment 275000 and facilities services employed 400 000. To these should be added in-house construction and maintenance activities, which represent roughly one-third of total construction.

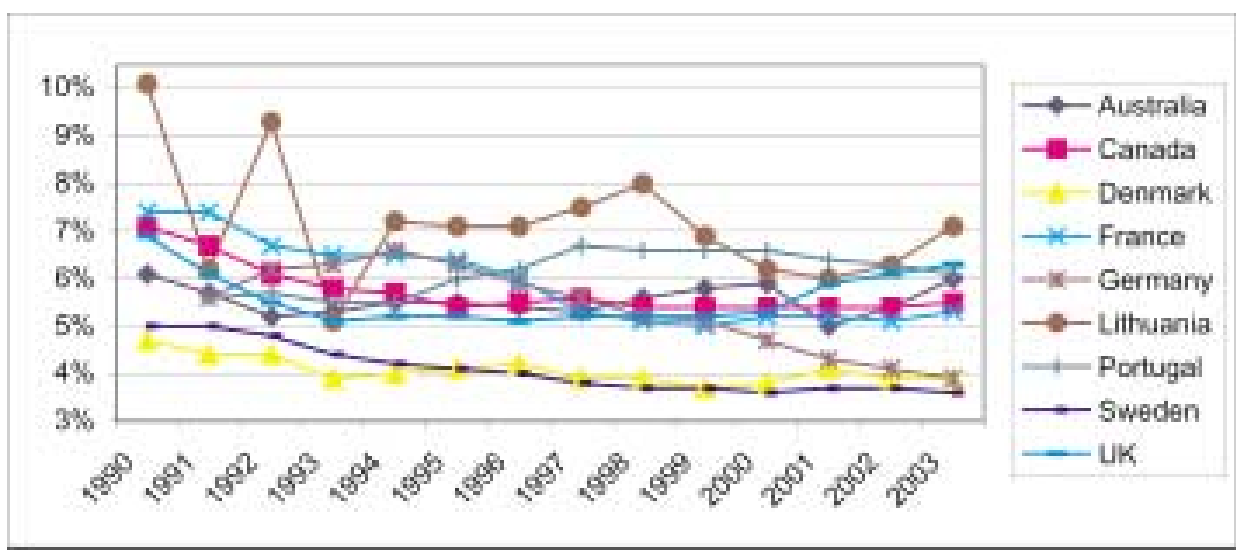

Figure 3. Construction value - added (construction firms only) share in GDP (1990-2003 constant prices)

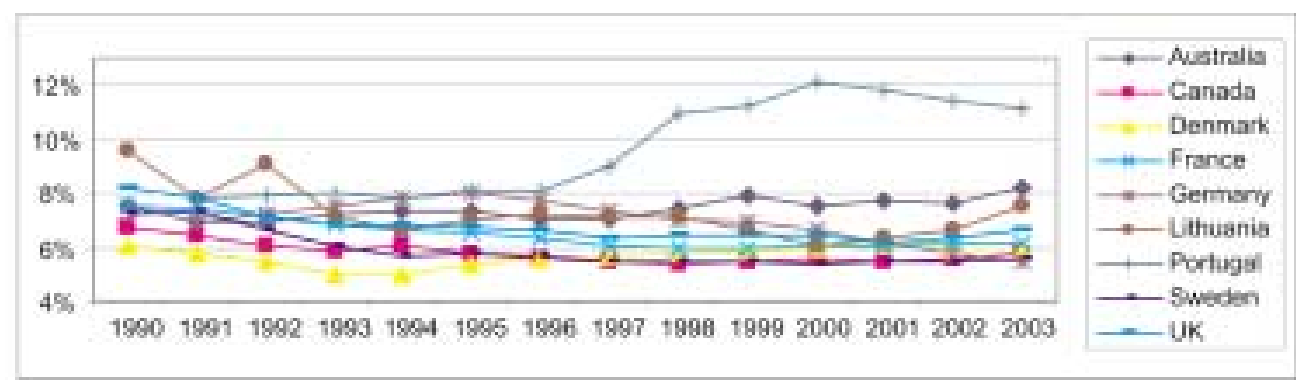

Figure 4. Construction employment share (construction firms only) in national employment (1990-2003) 
Increasing importance of managing the existing stock

Repair and maintenance represent more than $45 \%$ of construction work in most of the countries studied. This percentage is lower in Germany and Canada, but is not less than $23 \%$. However, it seems much lower in Portugal. Repair and maintenance activity is not as well represented in the official statistics as new construction due to do-it-yourself activity and the black economy. In Western Europe, it probably represents half of construction works. It is especially important in the housing sector (see Table 5).

Beyond repair and maintenance, managing the existing stock is becoming a strategic issue for companies and government. The impact of Facilities Management and Public Private Partnership are strong signs of this trend.

For housing, the value of the existing stock is easy to assess. Non-residential buildings and civil engineering infrastructures are difficult to evaluate and are often underestimated. Estimation methods are not the same from one country to another. Total construction stock represents from 1.6 times (in Sweden) to 4 times the GDP (in Germany).

Big companies coexist with a very fragmented built environment cluster

Fragmentation of the construction industry and the built environment cluster is a common characteristic of all countries.

In 2000, in the European Union, the relative importance of firms with less than $10 \mathrm{em}$ ployees firms varied from $82 \%$ of the total firms (Germany) to $95 \%$ (United Kingdom) (Ministère de l'Equipement, des Transports et du Logement, 2003).

In Australia, $94 \%$ of construction companies had less than 5 employees in 1997. In Canada, $96 \%$ of firms had annual revenue under Canadian $\$ 2 \mathrm{M}$ in 2000. This fragmentation characterises the construction industry in a market economy. In Lithuania, which has been moving from a planned economy to a market economy, the number of construction firms exploded from 1286 to 3452 between 1991 and 1999.

In 2001, in Europe, the part of the production of the companies with less than $10 \mathrm{em}-$ ployees varied from $24 \%$ (Italy) to $54 \%$ (United Kingdom). The one with companies with more than 250 employees accounted for between $8 \%$ (United Kingdom) and $35 \%$ (Spain). (Ministère de l'Equipement, des Transports et du Logement, 2003).

Instead of speaking of the fragmentation of the cluster, should we not speak of differentiation of a cluster characterised by its adaptation to the local demand? Most of the time, building (it is less true for civil engineering)

Table 5. New construction and repair \& maintenance (percentages of the value of the total construction production)

\begin{tabular}{|c|c|c|c|c|c|c|c|c|c|}
\hline$\%$ & $\begin{array}{l}\text { Australia } \\
\text { Estimate }\end{array}$ & $\begin{array}{l}\text { Canada } \\
(1997)^{*}\end{array}$ & $\begin{array}{l}\text { Denmark } \\
(2000)\end{array}$ & $\begin{array}{l}\text { France } \\
(2003)\end{array}$ & $\begin{array}{l}\text { Germany } \\
\text { (1999) }\end{array}$ & $\begin{array}{l}\text { Lithuania } \\
\text { (2003) }\end{array}$ & $\begin{array}{l}\text { Portugal } \\
(2000)\end{array}$ & $\begin{array}{l}\text { Sweden } \\
(2000)\end{array}$ & $\begin{array}{l}\text { UK } \\
(2003)\end{array}$ \\
\hline $\begin{array}{l}\text { New construction } \\
\text { Building }\end{array}$ & 36 & 41 & 33 & 41 & 51 & 28 & 68 & 25 & 43 \\
\hline $\begin{array}{l}\text { Repair \& maintenance } \\
\text { Building }\end{array}$ & 38 & 21 & 38 & 36 & 34 & 34 & 6 & 53 & $23 * *$ \\
\hline $\begin{array}{l}\text { New construction } \\
\text { Civil engineering }\end{array}$ & 20 & 36 & 17 & 15 & 11 & 13 & 24 & 17 & 11 \\
\hline $\begin{array}{l}\text { Repair \& maintenance } \\
\text { Civil engineering }\end{array}$ & 6 & 2 & 12 & 8 & 4 & 25 & 2 & 5 & $23 * *$ \\
\hline
\end{tabular}

* No longer available in Canada - discontinued

** Figures for building include only residential R\&M, and the figures for civil engineering include all non-residential R\&M (including commercial etc). 
deals with local markets, local clients and local firms.

Whilst small firms prevail in the industry, the industry is also characterised by, at the other extreme, some very large companies. In 2002, in Europe, two companies employed over 100000 employees (Vinci and Bouygues), and thirteen had a turnover of more than -4.2 billion. Most of those big companies have a "built environment cluster" approach, including services activities. To get more recurrent profits, they develop road construction and maintenance, electricity works, concession contracting and facilities management.

\section{LESSONS LEARNED AND IMPLICATIONS}

The built environment cluster approach brings at least four major implications for strategic management of construction firms and policy development.

Firstly, despite repeated efforts by governments in many countries, the performance of the industry using measurements such as the rate of productivity growth, levels of research and innovation, training and process improvement, is often seen as poor. An important part of the explanation for this failure of industry policy was, in the past, a misunderstanding of the industry's extent, due to inadequate determination of the size and scope of the building and construction industry, and the implication of that for policy initiatives. The built environment cluster approach is a convenient basis to build new performance indicators that will take into account the changing nature of the industry. The built environment cluster approach highlights the need to improve statistical data about construction and to link building and property economics. The main deficiencies in statistical data concern the nonresidential stock on the one hand and compa- nies and government in-house construction and maintenance departments on the other. These deficiencies are crucially important, as, at the beginning of the $21^{\text {st }}$ century, one new role for the construction industry is to improve the efficiency of this stock and its managing systems. Improving those statistical data will facilitate international comparisons. From an academic point of view, separation between building economics and property economics is becoming obsolete. Recent Public Private Partnership contracts, underline the needs of clients, dealing not only with design and build, but also with stock demolition, project financing and long-term maintenance ${ }^{1}$.

Secondly, strategic management of construction firms and projects requires an integrating perspective from client needs, design, supply of customized material and assemblies to services for operations and maintenance - taking into consideration the overall built environment cluster. The use of Web-based information and intelligent systems helps in developing an integrative approach for the management of complex construction projects.

Thirdly, the built environment cluster approach, based on the built facilities' life-cycle and its comprehensive players system, is an excellent starting point for sustainable development analysis in the construction field. Safety, health and environmental issues will be essential during the $21^{\text {st }}$ century. Public regulation is currently focused on new construction rules. The sector system analysis emphasizes the importance of existing stock for real improvement in the safety, health and environmental issues. It gives a new framework for sustainable development, not only in terms of analysis but also in terms of public regulation.

Fourthly, a built environment cluster approach is particularly helpful for understanding innovation processes and changes in the

\footnotetext{
1 See for instance the recently completed 705 Euros millions British Home Office contract involving HSBC and Bouygues, concerning the demolition of a property in London, design and build of new headquarters and housing estate, financing through bond loans and 26 years facilities management of the new property.
} 
industry. We may briefly mention the key roles of the following related sectors to construction:

Architects and engineers in designing new structures integrating new materials and using new construction equipment. Facility owners and managers in demanding new types of buildings or facilities for new functionality or usage as well as for improved performance in operating and maintaining these facilities. Public authorities and policies in promoting improved practices and products for security and environmental aspects.

Manufacturing suppliers - with competition from other material and suppliers - in developing new construction products and services. Research and education institutions for ensuring development of a sustainable competitive industry, with the help of developing strategic knowledge, new technologies and highly skilled personnel.

Without taking into consideration these actors, changes and improvement in the construction industry can hardly be understood. These actors are closely linked and work together as partners in a number of projects.

The built environment cluster analysis offers a framework which is the starting point of new analysis taking into account the changing nature of the construction industry at the beginning of the $21^{\text {st }}$ century.

\section{REFERENCES}

AEGIS (1999) Mapping the Building and Construction Product System in Australia, Department of Industry, Science and Resources, Canberra.

Andersson, N. (2003) A Mesoeconomic Analysis of the Construction Sector, Lund University, Lund.

Ascher, F. and Lacoste, J. (1972) Les producteurs du cadre bâti, Tome 1 : Les obstacles au développement de la grande production industrielle dans le secteur du BTP ; Tome 2 : Le développement des " mobiles homes " aux USA ; Tome 3 : Les entreprises de BTP, Université des Sciences Sociales de Grenoble, Grenoble.

Atkins, W.S. (1993) W.S. Atkins International, Strategies for the European sector construction, Eu- ropean Commission, Directorate General III/ 4173/93, Brussels.

Ball, M. (1998) Rebuilding Construction: Economic Change in the British Construction Industry. Routledge, London.

Bernstein, H.M. and Lemer, A.C. (1996) Solving the Innovation Puzzle. Chapter 6 in Challenges Facing the US Design and Construction Industry. American Society of Civil Engineers, p. 87107.

Berthier, J. P. (1992) Une analyse sur 20 ans de l'activité du bâtiment travaux publics, Économie et Statistique, 253, Institut National de la Statistique et des Études Économiques, Paris.

Bon, R. (1991) 'What Do We Mean by Building Technology', An Inaugural Lecture Delivered at the University of Reading, Reading, Berkshire.

Bon, R. (1992) The Future of International Construction': Secular Patterns Growth and Decline. Habitat International, 16(3), p. 119-128.

Bon, R. (1997) Whither global construction? ECERU Opinions Surveys 1992- 1997. Reading.

Bon, R. and Pietroforte, R. (1993) New Construction versus Maintenance and Repair Construction Technology in the US since World War II. Construction Management and Economics, 11(2), p. 151- 162.

Boublil, A. (1980) Construction, cadre de vie et croissance, Presses Universitaires de France, Paris.

Bourdeau, L. (1999) Sustainable development and the future of construction: a comparison of visions from various countries. Building Research and Information, 27(6), p. 354-366.

Boyer, R. (1996) Le capitalisme à la française à la croisée des chemins, in Crouch C. and Streeck W. (edited by), Les capitalismes en Europe (Paris: La Découverte).

Brandon, P.S. (1999) Sustainability in management and organization: the key issues? Building Research and Information, 27(6), p. 390-396.

Briscoe, G. (1988) The Economics of the Construction industry, Mitchell, London.

Campinos- Dubernet, M. (1984) Emploi et gestion de la main d'œuvre dans le BTP, Mutations de l'après guerre à la crise, Dossier N 34, Centre d'Études et de Recherches sur les Qualifications, Paris.

Campinos- Dubernet, M. (1996) Le BTP secteur spécifique? Une comparaison européenne. In 
L'innovation en chantiers, Plan Construction et Architecture, Paris La Défense, p. 15-24.

Carassus, J. (1987) Économie de la filière construction. Presses de l'École Nationale des Ponts et Chaussées, Paris.

Carassus, J. (1998) Production and management in construction, An economic approach (bilingual). Les Cahiers du CSTB, 395, Paris.

Carassus, J. (1999) Construction system: from a flow analysis to a stock approach. In Macroeconomic Issues, Models and Methodologies for the Construction Sector (edited by L. Ruddock), CIB, Publication 240, Rotterdam, p. 17-29.

Carassus, J. (2000) A Meso- economic Analysis of the Construction Sector. In CIB W55-W65 Joint Meeting Proceedings. The University of Reading.

Carassus, J. (2002) Construction: La mutation de l'ouvrage au service. Presses des Ponts et Chaussées, Paris.

Chemillier, P. (1977) Les techniques du bâtiment et leur avenir, Éditions du Moniteur, Paris.

CIB (1997) Future organisation of the building process W 82 Report, International Council for Building Research Studies and Documentation, 172, Rotterdam.

Curwell, S. and Cooper, I. (1998) The implications of urban sustainability. Building Research and Information, 26(1), p. 17-28.

De Long, J. and Summers, L. (1991) Equipment investment and economic growth. The Quarterly Journal of Economics, 106, May, p. 405-502.

du Tertre, C. (1989) Technologie, flexibilité, emploi, Une approche sectorielle du post-taylorisme, L'Harmattan, Paris.

du Tertre, C. (1991) Procès de travail de type chantier et efficacité économique: le cas du BTP français. In Europe et chantiers, Le BTP en Europe: structures industrielles et marché $d u$ travail, Plan Construction et Architecture, Paris La Défense, p. 119-137.

Egan, J. (1998) (Chairman of the Task Force). Rethinking construction, Department of the Environment, Transport and the Regions, London.

Finkel, G. (1997) The Economics of the Construction Industry, M. E. Sharpe, New York.

Hammond, D., Dempsey, J.J., Szigeti, F. and Davis, G. (2005) Integrating a performance- based approach into practice: a case study. Building Research and Information, 33(2), p. 128-141.
Hillebrandt, P.M. (1985) Economic Theory and the Construction Industry, Macmillan, London.

Holland, S. (1987) The Market Economy: From Micro to Mesoeconomics, Weidenfeld and Nicolson, London.

Ive, J. and Gruneberg, S.L. (2000a) The Economics of the Modern Construction Sector, Macmillan, London.

Ive, J. and Gruneberg, S.L. (2000b) The Economics of the Construction Firm, Macmillan, London.

Kohler, N. and Hassler, U. (2002) The building stock as a research object. Building Research and Information, 30(4), p. 226-236.

Latham, M. (1994) Constructing the Team, Industry Review of Procurement and Contractual Arrangements in the UK Construction Industry, HMSO, London.

Lipietz, A. (1974) Le tribut foncier urbain, Maspero, Paris.

London, K. and Russell, K. (1999) Client's role in construction supply chains: a theoretical discussion. In CIB W55 - W65 Joint Triennal Symposium, Customer satisfaction: A focus for Research \& Practice, Bowen, P. \& Hindle, R.

Lopes, J. (1998) The construction industry and macroeconomy in Sub- Saharan Africa post1970, Construction Management and Economics, 16(6), p. 637-649.

Manseau, A. (1998) Who cares about overall industry innovativeness? Building Research and Information, 26(4), p. 241-245.

Manser, J.E. (1994) Economics: A Foundation Course for the Built Environment, E.\&F.N. Spon, London.

Ministère de l'Equipement, des Transports et du Logement (2003) La construction en Europe, Direction des Affaires Economiques et Internationales, Paris.

Perloff, J.M. (2001) Microeconomics. Addison Wesley Longman, Harlow.

Pietroforte, R and Gregori, T. (2002) The Role of the Construction Sector in Highly Developed Economies, CIB W65 and W55 $10^{\text {th }}$ International Symposium - Construction Innovation and Global Competitiveness (Vol. 1), University of Cincinnati, USA.

Ruddock, L. (1999) Optimising the construction sector: A macroeconomic appraisal. In Macroeconomic Issues, Models and Methodologies for the Construction Sector (Edited by L. Ruddock), CIB, Publication 240, Rotterdam, p. 68-80. 
Ruddock, L. (2000) An international survey of macroeconomic and market information on the construction sector: Issues of availability and reliability. RICS Research Papers, 3(11), p. 1-17.

Sexton, M. and Barrett, P. (2005) Performancebased building and innovation: balancing client and industry needs. Building Research and Information, 33(2), p. 142-148.

Slaughter, E.S. (2000) Implementation of construction innovations. Building Research and Information, 28(1), p. 2-17.
Turin, D. (1973) The Construction Industry: Its Economic Significance and its Role in Development, UCERG, London.

Vincent, M. (1986) La formation du prix du logement, Economica, Paris.

Winch, G. (2000a) Construction business systems in the European Union. Building Research and Information, 28(2), p. 88-97.

Winch, G. (2000b) Institutional reform in British construction: partnering and private finance. Building Research and Information, 28(2), p. 141-155.

\section{SANTRAUKA}

\section{PERĖJIMAS NUO GAMYBOS PRIE PASLAUgU: İISAVINTOS APLINKOS KLASTERIO STRUKTŪRA}

\section{Jean CARASSUS, Niclas ANDERSSON, Artūras KAKLAUSKAS, Jorge LOPES, André MANSEAU, Les RUDDOCK, Gerard de VALENCE}

Statybos pramonė jau nebėra sutelkta ị vieno produkto tiekimą, t. y. ị pastatą ar fizinę infrastruktūrą, o teikia daugybę paslaugų ir siūlo tobulinti žmogaus aplinką. Pagrindinès tendencijos, tokios kaip subalansuota statyba ir subalansuotas aplinkos apstatymas, yra susijusios su reikšmingais pokyčiais. Tokie pokyčiai reiškia papildomus šios pramonès šakos vaidmenis ir naujų rodiklių, kuriais būtų galima ịvertinti jos rezultatus ir ekonominị poveikį, poreikị. Šiame darbe siūlomas naujas metodas, pagrịstas struktūros sukūrimu viso statybos ir nuosavybès sektoriaus analizei issisavintos aplinkos klasteris. Tai dalis tarptautinio tyrimo, atlikto devyniose šalyse: Australijoje, Kanadoje, Danijoje, Prancūzijoje, Vokietijoje, Lietuvoje, Portugalijoje, Švedijoje ir Jungtinëje Karalysteje. Poreikis patobulinti statistinius duomenis yra ypač pabrěžiamas šios pramonès šakos aprëpties didinimo kontekste. Šis naujas metodas tampa puikiu išeities tašku kuriant naujus rezultatyvumo rodiklius, kurie vertina kintantị pramonės šakos pobūdị, nustatant integracinę perspektyvą, suteikiančią pagrindą strateginiam valdymui, studijuojant subalansuotą plètrą statyboje ir siekiant suprasti inovacinius procesus ir pokyčius. Visapusè statybos šakos veiklos perspektyva yra būtina ir politikos iniciatyvoms, ir strateginei firmų analizei. 